\title{
Роль туризма в патриотическом воспитании молодежи
}

\author{
А.И. Зарытовская ${ }^{\bowtie}$, Л. П. Фролова \\ Воронежский государственный университет, Российская Федераџия \\ (394018, г. Воронеж, Университетская пл., 1)
}

\begin{abstract}
Аннотация: Цель - обратить внимание российского сообщества на воспитание молодежи с помощью всемерного развития туризма. Материалы и методы. Авторы на многолетнем педагогическом опыте работы с молодежью апробировали эффективность туризма на овладение школьниками и студентами сокровищами литературной и духовной культуры, природными особенностями и климатическим разнообразием России. Исходными данными для написания статьи стали туристские экспедиции, литературные материалы и материалы музейных экспозиций. Результатыл. Авторы акцентируют внимание на выдающихся культурно-исторических памятниках природы и архитектуры, расположенных в разных уголках нашей Родины. Но их особое внимание привлечено к событиям Великой Отечественной войны, 75-летие Великой Победы которое празднует в 2020 году российский народ и другие народы-победители.
\end{abstract}

Ключевые слова: патриотизм, воспитание молодежи, культурные и духовные ценности, туризм.

Для цитирования: Зарытовская А. И., Фролова Л.П. Роль туризма в патриотическом воспитании молодежи // Вестник Воронежского государственного университета. Серия: География. Геоэкология, 2020, № 2, c. 75-80. DOI: https://doi.org/10.17308/geo.2020.2/2889

\section{ВВЕДЕНИЕ}

На рубеже 80-90-х годов прошлого века в нашей стране произошло два важнейших события, которые коренным образом отразились на экономическом, социальном и духовном аспектах жизни народа. Первое из них - распад Советского Союза (декабрь 1991 года), второе - отказ от существовавшей в течение шестидесяти лет плановой социалистической системы хозяйствования, основанной на общенародной, государственной форме собственности на средства производства, и переход к рыночной экономике, в которой ведущие позиции занимает частная собственность на средства производства. Оба события оказали негативные последствия, связанные с угрозой территориальной целостности самой Российской Федерации и серьезным имущественным расслоением общества. Одновременно с этим произошел отказ от существовавшей в течение всех лет советской власти коммунистической идеологии (до 1917 года в стране была имперская идеология, обеспечивав- шая могущество Российской империи), цементировавшая и объединявшая все народы, живущие на территории СССР и России. Она основывалась на идее построения в стране социализма, а в будущем коммунизма, что было очень привлекательным, потому что направлялась на достижение всеобщего благополучия людей, их свободы, равенства и братства. Этим же целям служил провозглашенный в стране лозунг строителя коммунизма: «Человек человеку друг, товарищ и брат».

\section{МАТЕРИАЛЫ И МЕТОДЫ}

Важнейшее значение для поддержания высокого духовного уровня общества, помимо глубоких гуманистических начал, свойственных менталитету русского народа, имели и имеют наша культура и искусство. «Деидеологизация», происшедшая в связи с переходом к рыночной экономике, лежащей в основе капиталистического способа производства, привела не только к социальному неравенству, но и к некоторому ослаблению духовных ценностей, что достаточно тяжелым образом

() Зарытовская А.И., Фролова Л.П., 2020

$\triangle$ E-mail: deanery@geogr.vsu.ru

Контент доступен под лицензией Creative Commons Attribution 4.0 License. 
сказалось на моральном самочувствии многих людей, их веры в силу и мощь нашей страны, а также и в свои собственные силы. Поэтому на протяжении всех последних 29 лет существования России, как суверенного государства, шел поиск национальной идеи, которая сплотила бы многочисленные народы, живущие здесь. Высказывается мнение, что такая идея пока не найдена. Вопреки этому, нам представляется, что она существует. Ее можно обозначить одним словом - «патриотизм». На наш взгляд, эта идея является бесспорной, носящей всеобъемлющий, бессрочный характер. В русском языке патриотизм означает «преданность и любовь к своему отечеству, к своему народу» [4]. Именно поэтому мы считаем ее главной, основополагающей, так как нет ничего важнее преданности и любви к своему отечеству и народу.

Воспитание патриотизма у молодежи многовариантно, но одно из привлекательных его направлений, на наш взгляд, принадлежит туризму и, прежде всего, таким видам как познавательный, литературный, экологический. Основным их содержанием выступают знакомство и овладение сокровищами материальной и духовной культуры, а также природными особенностями, фантастического по красоте ландшафтного и климатического разнообразия страны. Через их познание с помощью туризма лучше, нагляднее и глубже молодому человеку можно понять красоту, величие и необъятность нашей Родины, громадные достижения отечественной цивилизации. Этим же целям служат учебные программы подготовки специалистов в Воронежском государственном университете для индустрии туризма как по стандартам среднего профессионального образования, так и бакалавриата [6].

Особое значение в патриотическом воспитании молодого поколения имеет посещение мест, связанных с образованием и постепенным расширением территории российского государства, его героической защитой от вражеских нашествий, с созданием величайших памятников и мемориалов Славы. Они свидетельствуют о непокорности, героизме и мужестве нашего народа, народа - победителя, который ценой жизни миллионов людей, живущих на территории России, отстоял свой суверенитет во время Великой Отечественной войны 1941-1945 годов. В этой связи, особенно важны туристические поездки в разные регионы страны - западные и северные, южные и восточные, где происходили ожесточенные сражения за свободу нашей Родины. Это необходимо для сохра- нения памяти в молодых поколениях о героических страницах истории России, понимания того, кто мы, каков наш вклад в мировую цивилизацию.

Решающую роль в организации всех побед с врагами имели обе столицы - Москва и Санкт- Петербург, а также их окрестности. Здесь сконцентрированы многочисленные монументы и мемориалы воинской Славы, историко-архитектурные, художественные, исторические, военно-исторические, литературно-мемориальные музеи и музеизаповедники, музеи изобразительных искусств, дома-музеи, музеи истории. Они имеются и во многих других городах, и в сельской местности России вместе с усадьбами дворянского быта, этнографическими и многими другими музеями, дворцовыми ансамблями и парками [5].

Центральная часть России является необычайно привлекательной для всех, кто интересуется древнейшими русскими городами - старинными центрами государственности и культуры, формирования древнерусской народности, с находящимися в них памятниками архитектуры, в том числе 12-13 веков. Они находятся в пределах существующего уже десятки лет необычайно популярного туристического маршрута «Золотое кольцо», охватывающего Владимирскую, Ивановскую, Костромскую, Московскую, Тверскую и Ярославскую области. В границах этих областей насчитываются десятки городов с уникальными соборами, церквями, монастырями, кремлями, музеями, в том числе под открытым небом, и другими достопримечательностями. Среди них первыми можно назвать Владимирскую землю и ее областной центр - город Владимир, сыгравшими большую роль в истории русского народа: Владимирские князья еще до возвышения Москвы стали «собирателями» русских земель. Во Владимире сохранились древнерусские памятники 12 века, Золотые ворота, Дмитриевский собор, Успенский собор, а в области - Церковь Бориса и Глеба в Кидекше, Церковь Покрова Богородицы на Нерли. В Суздале расположены Музей деревянного зодчества, Суздальский кремль, собор Рождества Богородицы, Архитектурный ансамбль Спасо-Елфимиевского монастыря и многое другое. Великолепнейшие памятники древней русской архитектуры подобного рода имеются и в других, названных выше, областях Центра России [5, 7].

Знаковыми событиями в истории нашего государства и народа, показывающими его беспримерный героизм, мужество, любовь к отечеству и имеющими чрезвычайное значение для воспитания у 
молодого поколения этих качеств, являются увековечение в народной памяти мест победоносных сражений, в которых проявился героизм российского народа. К ним относятся: Куликово поле в Тульской области, где в честь победы над татаромонголами в 1380 году сооружены памятник Дмитрию Донскому, храм-памятник Сергия Радонежского - вдохновителям и организаторам этой победы. Создан историко-архитектурный комплекс, включающий музейную экспозицию, памятники Красного холма и смотровую площадку с рельефной картой-схемой битвы; Бородинское поле в Московской области. Здесь на месте крупнейшего сражения Отечественной войны 1812 года с наполеоновской армией созданы военно-исторический музей-заповедник с историческим ландшафтом и 300 отдельными памятниками, а также военноинженерные сооружения Можайской линии обороны 1941-1942 годов в Великой Отечественной войне с немецко-фашистскими захватчиками. Они включают в себя доты, окопы, ходы сообщения, памятники на братских могилах павших советских воинов [5].

В честь величайшей Победы в Великой Отечественной войне, которая является главным предметом гордости российского народа на все времена, в нашей стране имеются многочисленные места воинской славы. Их посещение должно всегда быть несомненно первостепенным и приоритетным, если мы беспокоимся о патриотическом воспитании молодежи и об интенсификации развития туризма. Тем более важно, что в 2020 году мы празднуем 75- летнюю годовщину нашей Великой Победы над фашизмом. Молодое поколение не должно забывать о подвигах отцов и дедов и о миллионах жизней, отданных за спасение Родины, а значит нас всех.

Знание истории России невозможно себе представить без глубокого познания переломных моментов в ее существовании, когда решалась судьба государства, народа, сама их жизнь. Такими были 1941-1945 годы. Мы выстояли ценой громадных усилий и потерь, о которых наглядно можно увидеть и узнать, совершая, например, туристские поездки в Волгоград, в котором находится военно-исторический музей- панорама «Сталинградская битва» 1942-1943 годы, включающий панораму «Разгром немецко-фашистских войск под Сталинградом», бой на Мамаевом кургане 26 января 1943 года и соединение на его северо-западных склонах частей советских войск, разрезавших вражескую группировку на две части, музей «Сталин- градская битва» с мемориальными памятниками «Руины мельницы», «Стенка Родимцева», «Дом Павлова», где защитники города стояли насмерть, и многое другое [5]. Выдающийся советский поэт, писатель, военный корреспондент К. М. Симонов, пробывший в осажденном Сталинграде несколько месяцев в период самых ожесточенных боев, писал: «Да, здесь трудно жить, ибо небо горит над головой, и земля содрогается под ногами. Да, здесь трудно жить, больше того, здесь невозможно жить в бездействии. Но жить сражаясь, убивая врага, так жить здесь можно, так жить здесь нужно и так жить мы будем, отстаивая этот город среди дыма, огня и крови».

Перелом в Великой Отечественной войне наступил летом 1943 года в результате разгрома фашистов в Курской битве. Одним из решающих ее моментов было встречное танковое сражение у села Прохоровка Белгородской области. В честь этой победы здесь созданы военно-исторический музей-заповедник «Прохоровское поле», открыты военно-исторический комплекс, музей Прохоровского танкового сражения и ряд других музеев и памятников на территории Белгородской и Курской областей [5]. Мы назвали только некоторые героические памятные места битв и сражений, но их очень много на территории других областей нашей отчизны, о которых также нужно знать. Поэтому нельзя не говорить о них и не посещать регион России, недавно «вернувшийся» на свою историческую Родину, - Крым и, прежде всего, расположенный здесь город-герой Севастополь - главную военно-морскую базу Черноморского флота. Основанный в 1783 году после вхождения Крыма в состав Российской империи и называвшийся вначале Ахтиаром (белый утес) в 1784 году он был переименован в Севастополь, что в переводе с греческого означает «величественный город», «город славы». Впоследствии он многократно оправдает свое название. Это случится во время Крымской войны 1853-1854 годов при нападении на нашу страну коалиции Великобритании, Франции, Турции и Сардинии, желавших по меткому выражению Ф.И. Тютчева «преградить России путь в будущее», интервенции немцев, французов, англичан в 1918-1919 годы, боев с гитлеровскими и румынскими дивизиями в Великую Отечественную войну.

Севастопольскую оборону 1854-1855 годов называют героической. Она решала судьбу Крымской войны. В ней участвовал один из наших национальных гениев - Л. Н. Толстой, описавший ее 
в трех рассказах: «Севастополь в декабре», «Севастополь в мае» и «Севастополь в августе 1855 года». Писатель-воин, патриот восторженно показывает защитников Севастополя подлинными героями, в которых раскрылись глубинные коренные черты русского национального характера, во всю силу проявившиеся при защите своей земли от иноземных захватчиков. В рассказе «Севастополь в декабре» Л.Н. Толстой написал: «Не может быть, чтобы при мысли, что и вы в Севастополе, не проникли в душу вашу чувства какого-то мужества, гордости и чтоб кровь не стала быстрее обращаться в ваших жилах...». И далее наш национальный гений называет высокую побудительную причину в невозможности взять Севастополь, и не только взять Севастополь, но и поколебать где бы то ни было силу русского народа: «И эта причина есть чувство, редко проявляющееся, стыдливое в русском, но лежащее в глубине каждого, - любовь к родине».

Одним из важнейших пунктов обороны дважды был Малахов курган в X1X-XX веках. Здесь в Севастополе находится филиал музея-панорамы «Оборона Севастополя 1854-1855 годы», а сама панорама расположена в специальном здании города. На Малаховом кургане зажжен вечный огонь на могиле Неизвестного матроса в память героев, павших в боях за Севастополь. На Сапун-горе, взятую штурмом 9 мая 1944 года, создана диорама, посвященная освобождению Севастополя, беспримерному подвигу воинам-защитникам и освободителям.

Серьезное значение в патриотическом воспитании молодежи может иметь развитие литературного туризма, целенаправленное посещение мест, где родились, жили и творили писатели и поэты представители русской и советской классической литературы. В их произведениях ясно ощущается любовь к своей отчизне, к народу и природе, воспевание ее красот, что усиливает патриотические чувства и одновременно с этим способствует эстетическому воспитанию молодежи. В этой связи весьма отчетливой становится значимость и экологического туризма, являющегося вместе с этим одним из способов познания природы страны, не наносящий ущерба среде нашего обитания, нацеленный на экологическое образование и просвещение [1, 2].

Россия располагает огромным природным потенциалом для развития туризма. Обширность территории обеспечивает громадное разнообразие всех компонентов природы, вызывающих интерес у туристов: формы рельефа, климатические условия, водные объекты, растительность и ландшафты, особо охраняемые природные территории. К ним относятся заповедники, в которых запрещена любая хозяйственная деятельность (в том числе рекреационная) ради сохранения в нетронутом виде природных комплексов, охраны биологических видов и слежения за природными процессами; национальные (природные парки) - природоохранные, эколого-просветительские и научно-исследовательские учреждения, имеющие особую экологическую, историческую и эстетическую ценность. Поэтому очень важно знакомство с ними, как и с государственными особо охраняемыми природными территориями, в которых запрещены некоторые виды хозяйственной деятельности ради сохранения ландшафтов и восстановления редких и исчезающих биологических видов, ископаемых остатков флоры и фауны, водных объектов и экосистем памятников природы и, прежде всего, нетронутой природы.

\section{ЗАКЛЮЧЕНИЕ}

При патриотическом воспитании молодежи посредством познавательного, литературного и экологического туризма, его воплощение в практическую плоскость, необходимо иметь в виду непосредственную связь такого подхода с подготовкой кадров для индустрии туризма. Большие возможности для этого имеет факультет географии, геоэкологии и туризма, поскольку весь комплекс общих гуманитарных, социально- экономических, общих естественнонаучных и общепрофессиональных дисциплин так или иначе направлен на изучение нашей Родины, ее природных, экономических, социальных и культурных особенностей в территориальном аспекте.

\section{СПИСОК ЛИТЕРАТУРЫ}

1. Зарытовская А. И. Литературный туризм как фактор подготовки специалистов в экскурсионной сфере туристской отрасли // Вестник Воронежского государственного университета. Серия География. Геоэкология, 2018, № 3, с. 90-95.

2. География туризма, под ред. А. Ю. Александровой. Москва, КНОРУС, 2008, с. 508-541.

3. Кружалин В.И, Мироненко Н.С., ЗигернКорн Н. В., Шабалина Н. В. География туризма. Москва, Федеральное агентство по туризму, 2014. 336 с.

4. Ожегов С.И. Словарь русского языка. Москва, Рус. яз., 1991.915 c.

5. Российская музейная энщиклопедия. Москва, Прогресс: РИПОЛ классик, 2005. 845 с. 
6. Федотов С. В. Проблемы и перспективы подготовки университетских специалистов для индустрии туризма. Материаль международной научно- практической конференции «Рекреация и туризм в регионе: современные проблемы развития, территориальной организации и управления». Воронеж, 2010, с. 13-16.
7. Федотов С. В., Федотов В.И. Континентальный туризм в России. Современные доминанты // Вестник Воронежского государственного университета. Серия География. Геоэкология, 2017, №3, с. 5-11.

Конфликт интересов: Авторы декларируют отсутствие явных и потенциальных конфликтов интересов, связанных с публикацией настоящей статьи.

Поступила в редакциию 11.11.2019

Принята к публикаичии 02.06.2020

\title{
METHODOLOGY
}

UDC 37.035:796.5

ISSN 1609-0683

DOI: https://doi.org/10.17308/geo.2020.2/2889

\section{The Tourism Importance in the Youth Patriotic Education}

\author{
A. I. Zarytovskaya ${ }^{\circledR}$, L.P. Frolova \\ Voronezh state University, Russian Federation \\ (1, Universitetskaya pl., Voronezh, 394018)
}

\begin{abstract}
The purpose is to draw the attention of the Russian community to the education of youth through the comprehensive development of tourism. Materials and methods. The authors, over many years of pedagogical experience, have tested the effectiveness of tourism for schoolchildren and students to learn Russian literary and spiritual culture, the natural features and climatic diversity of Russia. Tourist expeditions, literary materials and materials from museum expositions were the initial data for writing the article. Results. The authors focus on outstanding cultural and historical monuments of nature and architecture located in different parts of our Motherland. But their special attention was drawn to the events of the Great Patriotic War, the 75th anniversary of the Great Victory which is celebrated in 2020 by the Russian people and other victorious peoples.
\end{abstract}

Key words: patriotism, youth education, cultural and spiritual values, tourism.

For citation: Zarytovskaya A. I., Frolova L.P. The Tourism Importance in the Youth Patriotic Education. Vestnik Voronezskogo gosudarstvennogo universiteta. Seria Geografia. Geoekologia, 2020, No. 2, pp. 75-80. (In Russ.) DOI: https://doi.org/10.17308/geo.2020.2/2889

\section{REFERENCES}

1. Zarytovskaya A.I. Literaturnyy turizm kak faktor podgotovki spetsialistov v ekskursionnoy sfere turistskoy otrasli [Literary tourism as a factor of training specialists in the excursion sphere of the tourism industry]. Vestnik Voronezskogo gosudarstvennogo universiteta. Seria Geografia. Geoekologia, 2018, no. 3, pp. 90-95. (In Russ.)

2. Geografiya turizma, pod red. A. Yu. Aleksandrovoy [Geography of tourism]. Moscow, Publ. KNORUS, 2008, pp. 508-541. (In Russ.)
3. Kruzhalin V.I, Mironenko N. S., Zigern-Korn N. V., Shabalina N.V. Geografiya turizma [Geography of tourism]. Moscow, Publ. Federal'noe agentstvo po turizmu, 2014. 336 p. (In Russ.)

4. Ozhegov S.I. Slovar' russkogo yazyka [Dictionary of the Russian Language]. Moscow, Publ. Rus. yaz., 1991. 915 p. (In Russ.)

5. Rossiyskaya muzeynaya entsiklopediya [Russian museum encyclopedia]. Moscow, Publ. Progress: RIPOL klassik, 2005. 845 p. (In Russ.)

6. Fedotov S. V. [Problems and prospects of training of university specialists for the tourism industry]. Materialy

(C) Zarytovskaya A.I., Frolova L.P., 2020

$\triangle$ E-mail: deanery@geogr.vsu.ru

The content is available under Creative Commons Attribution 4.0 License. 
mezhdunarodnoy nauchno-prakticheskoy konferentsii "Rekreatsiya i turizm v regione: sovremennye problemy razvitiya, territorial'noy organizatsii i upravleniya” [Proc. Int. sci.-pract. conf. "Recreation and Tourism in the Region: Modern Problems of Development, Territorial Organization and Management"]. Voronezh, 2010, pp. 13-16. (In Russ.)

Зарытовская Александра Ивановна кандидат географических наук, доцент кафедры рекреационной географии, страноведения и туризма Воронежского государственного университета, г. Воронеж, Российская Федерация, ORCID:

https://orcid.org/0000-0003-1702-2276, e-mail: deanery@geogr.vsu.ru

Фролова Людмила Петровна

кандидат педагогических наук, преподаватель кафедры рекреационной географии, страноведения и туризма Воронежского государственного университета, г. Воронеж, Российская Федерация, ORCID: https://orcid.org/ 0000-0002-5600-8891, e-mail: deanery@geogr.vsu.ru
7. Fedotov S. V., Fedotov V.I. Kontinental'nyy turizm v Rossii. Sovremennye dominanty [Continental tourism in Russia. Modern dominants]. Vestnik Voronezskogo gosudarstvennogo universiteta. Seria Geografia. Geoekologia, 2017, no. 3, pp. 5-11. (In Russ.)

Conflict of interests: The authors declare no information of obvious and potential conflicts of interest related to the publication of this article.

Received: 11.11.2019

Accepted: 02.06.2020

Aleksandra I. Zarytovskaya

Cand. Sci. (Geogr.), Assoc. Prof. of the Department of Recreational Geography, Country Studies and Tourism, Voronezh State University, Voronezh, Russian Federation, ORCID: https://orcid.org/0000-0003-1702-2276, e-mail: deanery@geogr.vsu.ru

Lyudmila P. Frolova

Cand. Sci. (Pedag.), Lecturer of the Department of Recreational Geography, Country Studies and Tourism, Voronezh State University, Voronezh, Russian Federation, ORCID: https://orcid.org/0000-0002-5600-8891, e-mail: deanery@geogr.vsu.ru 